Ana Sekelj

\title{
USVAJANJE VOKABULARA ENGLESKOG JEZIKA KAO STRANOG JEZIKA U RANOJ SKOLSKOJ DOBI
}

\author{
Prethodno priopćenje \\ Preliminary announcement
}

UDK 371.3:811.111'243

\begin{abstract}
Članak ukazuje na važnost vokabulara u procesu učenja engleskog jezika kao stranog jezika i to prvenstveno u periodu ranog učenja, jer kvaliteta iskustva učenja stranog jezika na početku školovanja bitno određuje daljnji proces učenja. U prvoj, ranoj fazi učenja naglasak je na vještinama slušanja i govorenja, jer učenici trebaju savladati vještinu čitanja i pisanja najprije na materinskom jeziku. U prikazivanju tehnika podučavanja vokabulara posebno se naglašava uloga priče, jer je afektivni čimbenik izuzetno važan u razdoblju ranog učenja. Ukazuje se također na činjenicu da izbor priče i razina jezika trebaju biti primjereni dobi učenika i njihovu znanju o jeziku i znanju o svijetu.
\end{abstract}

Ključne riječi: rano učenje, jezične vještine, vokabular, tehnike podučavanja

\section{Uvod}

Ljudski rod ima prirodnu sklonost stvaranju značenja, a najrazvijeniji sustav za to je jezik. Gramatičke strukture same po sebi nemaju nikakvu moć izražavanja značenja, osim ako nisu uporabljene riječi. Važnost vokabulara ističe i Krashen (1982) smatrajući ga temeljem komunikacije. Ako sugovornici ne prepoznaju značenje ključnih riječi, ne mogu biti u stanju sudjelovati u razgovoru. Žele li izraziti svoje mišljenje ili tražiti informacije, moraju biti u stanju proizvesti leksičke oblike koji će prenijeti njihovo značenje. Krashen (1982) ne smatra ispravnim pristup koji svjesno sužava usvajanje vokabulara dok se savladava morfologija i sintaksa, jer je vokabular isto tako važan u procesu usvajanja jezika. Na temelju svog "prirodnog pristupa" on smatra da se vještina komunikacije uglavnom brzo usvaja, dok se gramatička točnost razvija polako i uz duže iskustvo uporabe jezika. Ako je to točno, onda se, smatra Lewis (1993), konvencionalnim načinom podučavanja malo može učiniti, a u aktivnostima koje pružaju zadovoljstvo i u opuštenoj atmosferi mogu se postići bolji rezultati nego napornim radom. Ključni elementi "prirodnog pristupa" - naglasak na slušanju, važnost vokabulara na svim razinama, posebno na početnoj, nenaglašavanje točnosti jezičnih struktura i iznad svega središnji položaj značenja - bitni su elementi leksičkog pristupa koji predlaže Lewis (1993).

Ako govorimo o vokabularu u užem smislu riječi, očito je da sve riječi nisu jednako rabljene, i pri izboru vokabulara treba uzeti u obzir učestalost, raspon (mogućnost pojave riječi u različitim situacijama) i pokrivanje (riječi relativno širokog značenja koje se mogu javiti i sa specifičnim značenjima). Prema tome različiti jezični oblici mogu imati različite položaje u spektru komunikativne moći. Možemo govoriti o vokabularu i s aspekta vjerojatnosti i ocjene točno/ pogrešno. No učenici mogu proizvesti iskaze koje ne možemo uvijek vrednovati na temelju kriterija točno/pogrešno, jer iskaz koji je prihvatljiv u jednoj fazi učenja može biti neprihvatljiv u drugoj, što zahtijeva prilagodljivost učitelja. U ovom slučaju govorimo o spektru prihvat- 
ljivosti. Ovo su samo neki primjeri sagledavanja i analize svojstava jezičnih oblika s aspekta leksičkog pristupa.

Prema Readu (2000), vokabular nije samo skup leksičkih jedinica, već je to kompleksan proces, koji se u praksi ostvaruje kao znanje vokabulara i sposobnost njegove uporabe u komunikaciji, pa prema tome ovi segmenti određuju opseg znanja vokabulara u jeziku cilju.

\section{Uloga vokabulara u razvijanju jezičnih vještina 2.1. Slušanje}

Razumijevanje poruke je prva faza učenja bilo kojeg jezika i znanje jezika uključuje sposobnost razumijevanja slušanjem neograničenog broja rečenica i iskaza. Receptivna vještina razumijevanja govora prethodi razvoju produktivne vještine govorenja.

Razvijanje vještine slušanja prvi je preduvjet dobrog razumijevanja stranog jezika. U početnoj fazi učiteljica je prvi i jedini model s kojim se susreću i puno će vremena slušati učiteljicu dok igraju jednostavne igre, pjevaju pjesmice ili slušaju priče. Na učiteljici je da odluči koliko će od općeg razrednog jezika (upute, pitanja, pohvala...) biti na materinskom, a koliko na stranom jeziku, svakako postupno povećavajući taj omjer u korist stranog jezika. U toj dobi učenici se puno bolje koncentriraju na slušanje i razumijevanje onog što slušaju ako su pritom aktivno uključeni i izvode određene radnje, jer slušanje kod male djece nikad ne treba biti pasivna aktivnost. Učenici trebaju znati da se od njih ne očekuje da razumiju svaku riječ, već treba tražiti samo globalno razumijevanje onog što slušaju. Važno je da im značenje bude jasno, a učiteljica će se poslužiti slikama, mimikom, govorom tijela i tako će učenici napredovati u znanju i proširivati svoje spoznaje o jeziku. Zadatak je učiteljice da učenike uputi i pomogne im u razvijanju strategija slušanja (Brewster, Ellis i Girard 1991).

Kazete su dobar izvor materijala za slušanje, ali je učiteljica još uvijek nezamjenjiv i jedini izvor, posebno u razrednoj interakciji. Ona je koristan izvor jezičnog materijala i osim toga pruža učenicima i neophodan izvanjezični kontekst važan za razumijevanje poruke. Dok učiteljica pripovijeda priču može prekidati, provjeravati razumijevanje, komunicirati s učenicima, uključiti in aktivno u pričanje priče, a to su u stvari oblici slušanja kojima smo izloženi u svakodnevnom, stvarnom životu.

\subsection{Govorenje}

Poznavanje normi govornog ponašanja koje vrijede za neku govornu zajednicu neophodno je ako se želimo uspješno služiti tim jezikom jer komunikativna kompetencija podrazumijeva jezičnu ispravnost iskaza i primjerenost njegove uporabe. U suvremenom pristupu nastavi stranih jezika naglašava se uporaba jezika u autentičnim komunikacijskim situacijama. Međutim, školski uvjeti učenja postavljaju određena pravila igre, te se govorne aktivnosti razlikuju od prirodne komunikacije, nastavnik in kontrolira i usmjerava u skladu s ciljevima nastave, a želje govornika i slušatelja često su zanemarene. Principi sustavnosti i postupnosti na kojima se temelji nastava stranog jezika određuju nastavni proces i sadržaje, jezične strukture i vokabular su dozirani i kontrolirani i samim time se jezične aktivnosti u razredu razlikuju od autentičnih.

Jasno je da učenici uvijek razumiju više nego što su u stanju iskazati i također imaju izvjestan period šutnje (silent period) u kojem slušaju jezik koji uče, usvajaju ga, oblikuju svoju gramatiku, koju prilagođavaju i proširuju kako napreduju u učenju uz sve veću izloženost jeziku. Treba poštivati taj period u procesu učenja jezika i ne prisiljavati djecu na jezičnu aktivnost dok još nisu spremna da to spontano učine.

Da bi ovladali vještinom govorenja, učenici moraju najprije usvojiti neke elemente jezika kao što su vokabular, izgovor, strukture, jezične funkcije i dr. Zato je najjednostavnije učiti in najprije 
kraće izraze i izraze svakodnevne razredne komunikacije da se priviknu na glasove, da osjete ritam jezika, a da pritom nisu previše opterećeni time kako da oblikuju ono što žele reći.

Većina djece izjednačava proces učenja stranog jezika s učenjem govora i žele što prije moći govoriti. Takvu početnu motivaciju treba iskoristiti i održati, treba im što prije dati mogućnost da nešto progovore na engleskom jeziku da bi imali osjećaj da napreduju. Zato se obično počinje s temeljnim vokabularom koji je blizak dječjem svijetu i koji će im dati osjećaj da mogu komunicirati. U početnoj fazi učenja ne možemo još govoriti o spontanom govoru, a koji je poznat kao jezik formula (formulaic language) (Brewster, Ellis i Girard 1991). On se sastoji od rutinskih oblika koje djeca memoriraju i koji im omogućavaju da komuniciraju i s minimumom jezične kompetencije jer se ponavljaju, djeca in brzo uče i imaju osjećaj da mogu puno govoriti (Hello!, How are you?, What's the weather like today?, Sit down!...). Govorne aktivnosti koje se provode tijekom nastavnog sata mogu ići progresivno, od onih koje se temelje na vrlo kontroliranoj vježbi, do onih koje omogućavaju slobodnu komunikaciju (Brewster, Ellis i Girard 1991).

Ovladavanje vještinom govorenja nemoguće je bez vladanja fonološkom komponentom jezika. Prednost učenja jezika u ranoj dobi je u tome da brže i bolje usvajaju izgovor od starijih učenika. Zadatak je učiteljice, kao prvog i temeljnog uzora, da maksimalno iskoristi te prednosti, da stalno kontrolira i korigira izgovor, jer ograničena izloženost jeziku u školskim uvjetima učenja ne daje učenicima dovoljno prilike za samokorekciju.

\section{3. Čitanje}

Čitanje je kompleksan proces, ovisi o jezičnom znanju čitaoca i, da bi čitanje bilo uspješno, on mora primijeniti sve komponente jezičnog znanja. Čitanje se naziva "psiholingvističkom igrom predviđanja" (psycholinguistic guessing game) zbog mogućnosti pogrešnih predviđanja koja su kod dobrih čitača minimalna, jer ih oni brzo ispravljaju. Čitanje je kompleksan proces interakcije misli i jezika, interakcije jezičnog znanja i znanja o svijetu (Petrović 1988).

Kod početnog čitanja, kojemu je cilj savladavanje grafičkog sustava, važno je da vokabular i strukture budu uglavnom poznati, da učenici mogu obratiti pozornost na značenje teksta. Čitanje treba biti sastavni dio podučavanja stranih jezika, a dugoročni cilj treba biti osposobljavanje učenika za samostalno čitanje, jer će za veliki broj učenika nakon završetka školovanja to možda biti jedina vještina kojom će se služiti na stranom jeziku. Kad govorimo o početnom čitanju u fazi ranog učenja, treba imati na umu da mu treba prethoditi određeno razdoblje govornog jezika da se učenici što bolje upoznaju s fonološkim sustavom. Istovremeno, čitanje u nastavi engleskog jezika moglo bi, zbog razlika fonološkog i grafičkog oblika riječi, izazvati interferenciju ortografije u usvajanju izgovora. Učiteljica treba procijeniti kad su njezini učenici spremni za početak čitanja i treba voditi računa o tome koliko su dobro ovladali vještinom čitanja na materinskom jeziku, je li im čitanje na tom stupnju potrebno, služe li se istim pismom u usvajanju materinskog jezika, pokazuju li interes za čitanje i što će čitati (riječi, rečenice ili priče). Svakako treba uzeti u obzir i prirodnu dječju radoznalost, jer jednostavno žele otkriti kako se ono što su naučili izgovoriti može pročitati i napisati, a osim toga misle da im to može pomoći u zapamćivanju struktura i vokabulara.

Čitanje u ranoj fazi učenja engleskog jezika na razini je riječi, izvodi se uz jednostavne igre (Bingo, Domino...) da bi uvježbavali prepoznavanje riječi, i svakako im je potreban slikovni stimulans kao kontekst za razumijevanje riječi. Čitanje slikovnica naglas uz pokazivanje slika i riječi dobar je način uvođenja u čitanje, jer na taj način učenici počinju povezivati glas i značenje s pisanim simbolima. Primjenom vizualnih sredstava (slike, kartice) mogu se umanjiti moguće teškoće zbog uvođenja novoga grafičkog sustava. Širok je raspon aktivnosti koje se mogu provoditi s mlađim učenicima, od vježbi za razvijanje glasovnih vještina, za stimuliranje prepoznavanja ključnih riječi do onih složenijih koje vode k uvježbavanju složenijih vještina kao što su govorenje, slušanje ili pisanje (Brewster, Ellis i Girard 1991). 


\subsection{Pisanje}

Za pravilan pristup razvijanju vještine pisanja potrebna je svijest o razlici između govorne i pisane komunikacije. Prva bitna razlika između govorne i pisane komunikacije očituje se već u tome da je govor spontana jezična manifestacija, dok je pisani tekst rezultat osmišljenog odabiranja i sređivanja vokabulara i struktura, ideja i podataka, rezultat razmišljanja. U govornoj komunikaciji sugovornici mogu mijenjati sadržaj i način izražavanja ovisno o reakcijama sugovornika i sama komunikacija se znatno naslanja na izvanjezični kontekst, geste i mimiku. Osim toga govornik ima stalnu sugovornikovu povratnu informaciju, verbalnu i neverbalnu. U govoru je dopuštena određena jezična nedotjeranosts nedovršenim i isprekidanim rečenicama, ponavljanjima, dodatnim objašnjenjima, i zbog toga treba postupnim savladavanjem niza vještina težiti k razvijanju sposobnosti tečnog, jasnog i preciznog pisanog izražavanja.

Odluka o tome kad započeti učiti djecu pisati na engleskom jeziku vezana je uz odluku o početku podučavanja vještine čitanja. Pri donošenju odluke treba uzeti u obzir kako su savladali vještinu čitanja i pisanja na materinskom jeziku, koje je pismo kojim se služe u materinskom jeziku, pokazuju li zanimanje za pisanje, hoće li engleski sustav pisanja smetati u pisanju na materinskom jeziku, hoće li se od njih tražiti samo prepisivanje ili i kreativno pisanje i u skladu s tim hoće li, ovisno o ciljevima, to biti pisanje na razini riječi, rečenice ili teksta i priče. Pisanje je više od jednostavnog mehaničkog ispisivanja riječi, to je proces koji istovremeno zahtijeva kreativnost, točnost, poznavanje struktura i interpunkcije, izbor prikladnih riječi i povezivanje rečenica na razini teksta.

Kad se radi o uvođenju pisanja za mlađe učenike, važno je da ono započinje uz vizualni stimulans. Jednostavne vježbe prepisivanja riječi i rečenica imaju svrhu koliko uvježbavanja rukopisa toliko i pisanja na engleskom jeziku, a vokabular i jezične strukture tih rečenica obično su ograničeni. Diktat je jedan od najstarijih oblika pismenih vježbi i složeniji je od običnih vježbi prepisivanja, jer za vrijeme pisanja diktata učenici pretvaraju slušani tekst u pisani oblik, što zahtijeva dobro razumijevanje slušanog teksta, segmentiranje govornog niza prepoznatljive jedinice i na kraju dolazi pisanje (Petrović 1988). Pisane se vježbe s naglaskom na vokabular i gramatiku najčešće zasnivaju na dopunjavanju, supstituciji ili sintezi. U nastavi stranih jezika često se primjenjuju i pisani sastavi. U radu s mlađim učenicima to će obično biti vođeni sastavi pisani na osnovi crteža, slika ili stripova ili tako da im se daju osnovne misli i ključne riječi u obliku natuknica koje će u pisanju slijediti. Mlađim učenicima potrebno je takvo vođenje da nauče nizati svoje misli o određenoj temi logičnim slijedom, da ono što napišu ima određeni sadržaj i predstavlja smislenu cjelinu.

\section{Učenje vokabulara na početnoj razini}

Suvremeni procesi globalizacije, posebno kretanje u ujedinjenoj Europi, naglasili su potrebu da naši građani budu u stanju tečno se služiti stranim jezicima. Da bi se taj cilj mogao uspješno ostvariti, trebalo je proces učenja stranog jezika započeti u ranoj školskoj dobi, i pokazalo se da je dob od sedam godina vrlo povoljna, jer je, prema Piagetu, razdoblje od 7 do 11 godina faza "konkretnih operacija", u kojoj djeca, zbog svojih specifičnih psihofizičkih i kognitivnih mogućnosti, s lakoćom započinju učenje stranog jezika. U ovoj fazi dijete razumije ono što vidi, čuje, dodiruje, što mu omogućava da traži i dobije u svakodnevnoj komunikaciji, i očito je da je apstraktnost gramatičkog sustava nedokučiva, te zato treba izbjegavati bilo kakva objašnjenja ili tražiti mehaničko zapamćivanje pravila, jer to ničemu na služi. Bitno je da se dijete izrazi, pa makar to bilo i netočno. Ono na čemu pak treba ustrajati i zahtijevati točnost jesu izgovor, ritam, intonacija i ostala prozodijska sredstva, jer djeca te dobi mogu s lakoćom svladati izgovor bez stranog akcenta ako su izložena dobrom modelu (Vilke 1999). 
Učenici naših osnovnih škola uključeni su u proces ranog učenja, što je u skladu sa stavovima Vijeća Europe, koje je rano učenje stranog jezika odredilo kao jedan od prioritetnih zadataka u suvremenom obrazovanju. Vrijedno pozornosti je da se Hrvatska rano uključila u taj proces i postigla vrlo zapažene rezultate.

Sâm početak učenja u dobi od sedam godina još nije dovoljan da bi rezultati učenja bili zadovoljavajući, jer za uspješnost u učenju trebaju biti ispunjeni još neki uvjeti. To su prvenstveno male grupe od najviše 12 do 15 učenika i dovoljna izloženost učenju od 4 do 5 sati tjedne nastave. Sam način izvođenja nastave nije ništa manje važan i bitno se razlikuje od nastave drugih predmeta, jer se učenje stranog jezika ostvaruje u opuštenoj, vedroj atmosferi, uz zanimljive i poticajne aktivnosti (playful atmosphere) koje će djeci omogućiti da se uključe i izraze intelektualno, emocionalno i motorički (Vilke 1999).

Vokabular igra bitnu ulogu u komunikaciji i predstavlja temelj za izgradnju jezičnog znanja jer usvojenost gramatičkih struktura ne znači ujedno i ostvarenje komunikacijske kompetencije.

U procesu osnovnoškolskog obrazovanja u Hrvatskoj engleski jezik je uveden kao obvezni školski predmet od prvog razreda. Pažljiv odabir vokabulara je od izuzetne važnosti jer riječi koje će se učiti u ranoj školskoj dobi trebaju biti bliske djeci i u skladu s njhovim interesima. Vilke (1991) ističe potrebu da to moraju biti riječi čiji sadržaj djeca već poznaju iz materinskog jezika i, što je jednako važno, da se koncepti tih riječi trebaju odnositi na elemente iz njihovog okruženja i kulture, jer se puno teže uče i zapamćuju riječi uz koje treba usvojiti i nove koncepte. Vilke kao primjere navodi parove riječi kettle - bottle te television - fireplace, gdje kettle i fireplace izazivaju poteškoće i teže se pamte jer ih treba povezati s novim konceptima.

Jezik je nerazdvojan dio načina života i svjetonazora neke zajednice, i u procesu učenja materinskog jezika usvajaju se i koncepti koji se mogu razlikovati od koncepata u stranom jeziku, pa stoga učenje stranog jezika nije samo učenje jezika nego i usvajanje novih koncepata ili proširivanje usvojenih. Taj problem Vilke (1999) ilustrira primjerom riječi u hrvatskom jeziku ruka, koja se u engleskom jeziku pojavljuje u dva oblika s različitom uporabom hand i arm. Tijekom procesa učenja i usvajanja vokabulara djeca mlađe školske dobi, u skladu sa svojim procesom intelektualnog, psihičkog i motoričkog razvoja, stvaraju i razvijaju percepciju svijeta koja je bitno različita od one odraslog pojedinca, jer je, kako Vilke (1999) ističe, učenje i usvajanje riječi i njihova uporaba zapravo klasifikacija koncepata.

Budući da djeca mlađe školske dobi razvijaju i emocionalni odnos prema riječima, lakše će zapamtiti i rabiti riječi ako im je drag koncept koji one predstavljaju i o toj činjenici treba voditi računa pri uvođenju novih riječi. Vokabular koji se nudi učenicima te dobi svakako im treba omogućavati da govore o njima bliskom svijetu, a to je svijet igre, zabave, obitelji, škole, svijet životinja (Vilke 1999). Pri usvajanju vokabulara djeca će biti uspješnija u zapamćivanju riječi koje su bliske njihovom svijetu i onome što vole, dok će biti teže s riječima koje su apstraktne, koje ne postoje u njihovoj svijesti ili u kulturi materinskog jezika.

Udžbenici za učenje engleskog jezika na početnoj razini sadrže uglavnom vokabular koji imenuje osobe ili predmete iz neposredne okoline učenika (boy, girl, window, door...), jer su to riječi čije je značenje jasno, to su stvari koje oni mogu vidjeti i dodirnuti. $U$ toj fazi proces učenja se u dobroj mjeri oslanja na osjetila i to omogućava uspješno učenje. Znamo da postoje engleske riječi kao što su cowboy, rock star, koje učenici nauče izvan nastave i vrlo ih lako usvajaju, dok istovremeno i pored objašnjenja učitelja i niza vježbi, s više teškoća usvajaju riječi koje su prezentirane u udžbenicima.

Da bismo odgovorili na pitanje zašto učenici sporije uče strane riječi koje označavaju njima bliske predmete, moramo na vokabular gledati sa stajališta učenika. Oni već imaju zadovoljavajuće riječi na svom materinskom jeziku za sve ono što u svojoj okolini trebaju imenovati. Stoga većina njih ne osjeća stvarnu potrebu da sad nauči druge riječi za te iste stvari. Taj se problem ne pojavljuje kad se radi o riječima rock star i cowboy jer one označavaju nova iskustva koja nisu imenovana riječima u njihovom materinskom jeziku. Međutim kad se 
radi o temeljnim riječima, sa stajališta učenika one nisu neophodne, jer riječi u materinskom jeziku zadovoljavaju sve praktične namjene, njihova uporaba proizlazi iz konkretne situacije. Veću sposobnost praktičnog služenja vokabularom imaju oni koji uče riječi da bi zadovoljili svoje osobne potrebe i želje, a u školskim uvjetima učenja svakako je nemoguće još jednom stvoriti uvjete koji će pomoći učeniku da usvoji vokabular stranog jezika na isti način na koji je usvojio vokabular materinskog jezika.

U nastavi stranog jezika može se pokušati, kad je to moguće, omogućiti učenicima da dožive određeno iskustvo s predmetom prije nego što čuju i nauče riječ, jer će takav pristup kod učenika rane školske dobi stvoriti pozitivne preduvjete za uspješno učenje vokabulara. Poznato je da se novo znanje najbolje apsorbira ako može biti "uronjeno" u znanje koje već postoji i pohranjeno je u pamćenju učenika i učitelj ga treba aktivirati da olakša pristup novim riječima. Time će potaknuti proces asocijacija i otkriti moguće praznine u predznanju učenika, kako na razini vokabulara tako i na razini struktura.

U procesu učenja stranog jezika strategije učenja imaju vrlo važnu ulogu pa tako i u učenju i proširivanju vokabulara. Proces učenja treba promatrati kao cjeloviti proces implicitnog, uglavnom nesvjesnog usvajanja kroz izloženosti jeziku i eksplicitnog, sustavnog učenja u formalnim uvjetima. U uvjetima formalnog učenja učenici primjenjuju strategije vokabulara kao što su ponavljanje i ispisivanje riječi, učenje popisa riječi i ispitivanje samog sebe, zapamćivanje uz različite ilustracije, prijevodi itd. Učenje kroz izloženost jeziku cilju prvenstveno usmjerava pozornost na uporabu, a ne na učenje jezika kao sustava i taj se proces odvija uglavnom nesvjesno, pa su i strategije usvajanja drugačije. U ovom kontekstu poput bilježenja uz gledanje filmova i čitanje, povezivanje sa slikovnim materijalom, sa stvarnim predmetom, sa situacijom, zatim uporaba rječnika (tu svakako prednost ima slikovni rječnik), slušanje engleskih pjesama, zapamćivanje riječi s interneta, iz filmova i televizijskog programa (Pavičić i Umiljanović 2008). Budući da je engleski jezik vrlo prisutan u svim medijima kao sredstvo komunikacije, jasno je da će strategije spontanog usvajanja bitno pridonositi povećavanju vokabulara učenika.

Istraživanja su pokazala da postoji negativna korelacija između veličine vokabulara i strategije formalnog učenja, jer vokabular koji se npr. uči napamet, za ocjenu, za potrebe škole, se brzo i zaboravlja. Uspješnije su strategije spontanog učenja vokabulara iz pjesama, filmova, knjiga, interneta, televizijskog programa, jer su učenici sigurno motiviraniji u učenju radeći ono što vole i sam proces učenja odvija se zapravo nesvjesno. Ne treba zanemariti ni činjenicu da je prednost ovakvog učenja upoznavanje s leksičkim jedinicama u prirodnom kontekstu i na kraju, posebno kod učenika mlađe školske dobi, afektivni aspekt igra značajnu ulogu. Oni će s velikim veseljem izvoditi omiljene igre, pjevati pjesmice, čitati priče ili gledati filmove itd.

\section{Aktivnosti i tehnike podučavanja vokabulara za mlađe učenike}

Djeca mlađe školske dobi u usvajanju vokabulara primjenjuju specifične strategije u skladu sa svojim sposobnostima učenja i pokazalo se da je učenje najuspješnije ako im je dana mogućnost da predmet vide, dodiruju, opipaju i uključe ga u neku aktivnost. Uspješnosti učenja svakako će pridonijeti zainteresiranost učenika i pažljiv odabir vokabulara koji obuhvaća elemente iz njihovog svakodnevnog života i sadržaje koje su već obradili u ostalim predmetima kao što su priroda i društvo, matematika, hrvatski jezik i dr. Time se nastava stranog jezika, u ovom slučaju engleskog jezika, usmjerava k stjecanju znanja iz hrvatske kulturne, nacionalne i prirodne baštine. Budući da udžbenici uglavnom donose elemente anglosaksonskog okruženja, konačni je cilj nastave stranog jezika razvijanje međukulturalnog razumijevanja (Vickov 2008).

Već je ranije ukazano na ključnu ulogu koju ima nastavnik, prvenstveno kao jezični model, najčešće prvi i jedini kojega će slijediti, jer djeca mlađe školske dobi imaju neponovljivu sposob- 
nost imitacije fonetskog sustava i s lakoćom usvajaju izgovor. Osim toga važno je da nastavnik bude kreativan, dobar organizator svih aktivnosti i da i sam u njima sudjeluje.

Razumijevanje značenja je samo prvi korak u učenju riječi i ono ne treba oduzeti previše vremena, jer puno više vremena u nastavnom procesu treba posvetiti drugim aktivnostima, aktivnostima koje će od učenika zahtijevati da rabe nove riječi u odgovarajućim komunikacijskim situacijama.

\subsection{Vizualne tehnike}

Crteži i slike su nezamjenjivi u prezentiranju vokabulara na bilo kojoj razini učenja, a posebno na početnoj, jer mlađi učenici vole crtati, no kad god je to moguće treba donositi stvarne predmete u razred. Mimika i geste često služe kao dopunsko sredstvo prezentiranja značenja. Vizualna pomoćna sredstva dostupna su u različitim oblicima i treba koristiti mogućnost dodira i viđenja predmeta jer to pojačava vezu između predmeta i odgovarajuće riječi na engleskom jeziku. U ranoj fazi učenja pano i flanelograf su izuzetno korisni za privremeno izlaganje slika i učeničkih radova vezanih za nastavnu jedinicu. Opisivanje slike može koristiti za uvođenje novog vokabulara ili za ponavljanje već usvojenog.

Oponašanje svakako sadrži elemente vizualnog i ta je aktivnost pogodna za provjeravanje i utvrđivanje značenja riječi koje se odnose na pojedine predmete ili radnje koje učenici mimikom izvode. Izvođenjem radnji nakon zapovijedi učenici pokazuju da su razumjeli zapovijed i već na prvim satima engleskog jezika mogu se izricati zapovijedi koje se odnose na svakodnevne rutinske radnje ("Answer", "Repeat", "Please, sit down"...). One su korisne jer učenici pokazuju da razumiju vokabular. Osim toga učenicima rane školske dobi neophodna je fizička aktivnost nakon dužeg perioda sjedenja, pa uporaba riječi u jednostavnim zapovijedima potiče učenje vokabulara i pomaže da se održi pozornost i koncentracija.

\subsection{Igre}

Poznato je da je sposobnost koncentracije kod djece mlađe školske dobi kratka, 5 do 10 minuta, pa se aktivnosti moraju izvoditi u obliku igre u kojoj će djeca sudjelovati i jezično i fizički jer su pokreti i fizička aktivnost bitni u toj dobi. Vrlo uspješna tehnika učenja vokabulara total physical response pruža djeci veliko zadovoljstvo budući da im omogućava intenzivno kretanje i uporabu ostalih načina neverbalne komunikacije kao što su gluma, mimika... (Vilke 1993).

Posebno s psihološkog aspekta, igre imaju izuzetno važnu ulogu u procesu usvajanja engleskog jezika, pa tako i vokabulara, u ranoj školskoj dobi. Omogućavaju im da budu aktivni, a slušanje i razumijevanje može se iskazati izvođenjem određenih radnji (guessing games, "Simon says"...). Rivers i Temperly (1978) daju serije asocijativnih igara koje mogu pospješiti grupiranje riječi među kojima postoji povezanost. Učenicima se može dati zadatak da stvaraju nove riječi tako da mijenjaju po jedno slovo (man, map...), dodaju ili oduzimaju jedno ili više slova (ear, fear...) i slično.

\subsection{Pjesmice i rime}

U prvoj godini učenja treba izbjegavati pisanje i čitanje jer učenici tek trebaju savladati te vještine u materinskom jeziku, pa uvođenje sustava pisanja stranog jezika u toj fazi može samo izazvati zbrku. Umjesto toga može se, kad god je to moguće, iskoristiti njihova izvrsna sposobnost da u toj fazi uče napamet. Naročito su pogodne dječje pjesmice koje su obično kratke, jednostavne, lake za učenje i učenici ih uče s veseljem, jer usvajaju vokabular i strukture bez svjesnog napora koji je karakterističan za proces učenja kod starijih učenika. Pjesmice i rime pridonose stvaranju ležerne i opuštene atmosfere, što je svakako preduvjet uspješnosti učenja, 
jer znamo koliko važnu ulogu igra emotivni čimbenik u procesu učenja stranog jezika kod mlađih učenika. Te aktivnosti omogućavaju i fizičku aktivnost i izvanjezično ponašanje koje zadovoljava veliku potrebu djece te dobi za kretanjem.

\subsection{Slušanje, govorne aktivnosti i pričanje priča}

Kod provođenja govornih aktivnosti lako ćemo uočiti da učenici više razumiju nego što su sposobni iskazati, često ne mogu iskazati svoje misli, a i kad mogu zastajkuju usred rečenice da bi pronašli pravu riječ. U takvim situacijama vođeni razgovor može biti vrlo uspješan.

Učenike treba osposobiti da se služe strategijom postavljanja pitanja kad traže objašnjenje značenja riječi s kojom su se susreli. Pitanja i iskaze poput: "It's the thing you use for cleaning the floor., What's this called in English?, What's the opposite of beautiful?" (Gairns i Redman 1986) mogu rabiti da bi pitali za oblike koje ne znaju na engleskom a koje bi htjeli znati jer su im u određenim situacijama potrebni.

Općenito govoreći, posljednjih je godina priznat velik utjecaj priče na razvoj dječje komunikacije i jezične kompetencije u materinskom i isto tako i u stranom jeziku. Bruner tvrdi da je naša percepcija svijeta oblikovana pričama koje smo slušali i usvojli (Vilke 1995). Djeca rane školske dobi izuzetno vole priče i bajke i one svakako igraju veliku ulogu u oblikovanju karaktera djeteta. Pisane u poetskoj formi one govore o općim istinama i imaju pozitivan utjecaj na emocionalni razvoj djeteta. Likovi u pričama obično su prikazani kroz jednu jasno izraženu osobinu (slabi ili jaki, skromni ili ponosni, dobri ili zli) i zbog toga ih je lako razumjeti i poistovjetiti se s njima. U fazama djetinjstva dječji duh prolazi kroz period kad prevladava zanimanje za realni svijet, a onda dolazi do pojačanog zanimanja za svijet mašte. U određenom razdoblju razvoja dijete se nalazi između svijeta realnosti koji ga okružuje i svijeta koji izgleda kao da je stvaran, ali zapravo nije i dijete će rijetko zaista pobrkati realni svijet sa svijetom iz dječje književnosti (životinje, cvijeće... u pričama govore).

Dječja književnost mora imati kvalitete književno-umjetničkog djela kao što su glazbenost, osjetilne predodžbe, lijepe riječi, tajanstveni opisi i sve to treba biti iskazano neobičnim jezikom. Ući u svijet dječje književnosti znači ući u svijet pjesme, igre, poleta, svijet blistavih boja, divnih ilustracija, svijet pun iznenađenja, tajnovitosti s elementima mašte i svakodnevnog života. Ona razvija dječju maštu kroz zagonetke, pjesmice, smijeh i sreću, kroz bajke i poučne priče, kroz modernu znanstvenofantastičnu priču, priču o junačkim djelima ili o sukobu dobra i zla. Priče zadovoljavaju emocionalne, kognitivne i psihološke potrebe djeteta, njihovu potrebu da glume, dijele, da se osjećaju zaštićenima. Omogućavaju djetetu da se identificira s likovima i na taj način aktivno sudjeluje u događajima.

Pričanje priča zauzima svakako istaknuto mjesto u procesu ranog učenja stranog jezika, jer pruža djetetu bogato kulturološko i jezično iskustvo i stoga predstavlja izvrsno sredstvo za razvoj govornih vještina, a tu svakako vokabular ima dominantnu ulogu. Izbor priče mora biti prilagođen uzrastu učenika i njihovom jezičnom znanju. Priča treba imati jednostavnu strukturu, jasno definiranu i zanimljivu temu, dobro razvijenu fabulu sa zapletom i raspletom i snažan emotivni naboj. Isto tako pri izboru treba voditi računa je li ona pogodna za dramatizaciju, ima li dovoljno mogućnosti za integriranje kulturoloških, kognitivnih ili afektivnih elemenata, povezuje li dva dječja svijeta, svijet mašte i realni svijet i u kojoj se mjeri mogu u daljnjoj fazi rada primijeniti određene vježbe vokabulara i jezičnih struktura.

Da bi prezentiranje priče bilo uspješno, treba voditi računa o nekim čimbenicima:

- ponekad je potrebno stvoriti ugođaj (svjetlo, glazba...), dati uvodni komentar ili objasniti nove i teže riječi da ne bi omele razumijevanje priče

- važna je boja glasa i ton kojim se pripovijeda ili čita priču, jer djeluju na emotivni doživljaj

- učiteljica treba održavati stalni kontakt očima s učenicima, ne samo da održi njihovu 
pozornost, nego i da ima povratnu informaciju o tome kako i koliko razumiju ono što slušaju

- prirodna i primjerena gestikulacija i mimika mogu biti vrlo korisni

- ako se smatra potrebnim i korisnim, mogu se koristiti različiti predmeti i igračke

- ponekad prostor može biti potpuno neodgovarajući za pričanje priče i, da bi se stvorio bolji ugođaj, on se može prema potrebi preurediti (Pedersen 1995)

Aktivnost pričanja priče uključuje ponekad samo slušanje, ponekad igranje uloga i dramatizaciju ili čak pisanje vlastitih priča. Slušanje s razumijevanjem je bitno da bi pričanje priče bilo uspješno. Nakon prezentiranja priče mogu uslijediti različiti oblici govornih i pisanih vježbi, posebno za uvježbavanje vokabulara i jezičnih struktura. Kao efektan oblik aktivnosti nakon slušanja prirodnim slijedom dolazi dramatizacija i igranje uloga. Ta aktivnost predstavlja krunu rada, to je "šećer na kraju". Ne možemo zamisliti radost, veselje i uzbuđenje koje učenici mogu iskazati proživljavajući takvo iskustvo. Ta je aktivnost utoliko dragocjenija zbog svoje uloge na jezičnom planu. Kroz glumu djeca nauče zapamćivati vokabular, jer ponavljaju tekst nastojeći proizvesti prirodan govor, uče govor tijela, postavu glasa, način izražavanja, uporabu jezika u određenim situacijama itd.

\subsection{Aktivnosti čitanja i pisanja}

Aktivnosti čitanja i pisanja mogu biti raznovrsne, ovisno o kojoj se razini početnog učenja radi (od prvog do četvrtog razreda). Predviđanje vokabulara može biti aktivnost koja se provodi na temelju zadane teme. Učiteljica napiše na ploču zadanu temu, a učenici pokušavaju predvidjeti riječi koje se mogu povezati s tom temom. Te su asocijacije korisne kao uvod u čitanje nekog teksta ili mogu biti igra za sebe. Osim zagrijavanja (warming up) i pripreme za čitanje, takva aktivnost aktivira predznanje učenika i potiče radoznalost. U nešto drugačijem obliku ta aktivnost može poslužiti učenicima da pokušaju otkriti o kojoj će temi biti riječ.

Nakon što su provedene vježbe vještina slušanja, govorenja, čitanja i pisanja, aktivnosti sastavljanja popisa vokabulara mogu biti korisne kao završna aktivnost, kao konačna rekapitulacija vokabulara i učenici pritom mogu ponoviti sve riječi spomenute u temi i mogu ih grupirati u kategorije na temelju određenih kriterija. Bit će još zanimljivije ako se aktivnost provodi u grupama. U vježbi otkrivanja uljeza učenici na predloženom popisu riječi moraju otkriti koja se ne uklapa i mogu to pokušati obrazložiti. Ta aktivnost ne usmjerava pozornost učenika samo na značenje riječi, već i na njihove međusobne odnose proširujući učeničko znanje o mjestu riječi i njihovom leksičkom opsegu. Viša razina pismenog izražavanja mogu biti već ranije spomenuti vođeni sastavi.

Odlučujuća je uloga učiteljice u izboru aktivnosti i tehnika izvođenja nastave i njihovoj prilagodbi uzrastu, predznanju i potrebama učenika.

\section{Zaključak}

Brojni su čimbenici koji utječu na sposobnost učenika da nauči vokabular stranog jezika u razrednoj situaciji. Čimbenici koji ovise o učeniku uključuju njegov materinski jezik, prethodno iskustvo u učenju jezika, strategije učenja, motiviranost i dr. Poticanje pozitivnih i stimulativnih strategija od izuzetne je važnosti za proces učenja u cjelosti, pa tako i za učenje i proširivanje vokabulara.

U vezi s nastavnim procesom podučavanja vokabulara može se pojaviti problem određivanja prave mjere, jer ako nastojimo da učenik jasno i s razumijevanjem usvoji leksičke oblike sa svim njihovim konceptualnim granicama koje ih odvajaju od srodnih i povezanih oblika, moglo 
bi izgledati da u nastavi nema prostora za učenje bilo čega drugog osim vokabulara. Stoga je zadatak učitelja da utvrdi od kolike su važnosti pojedini oblici, posebno za mlađe učenike, koliko su oni neophodni za jezičnu produkciju u skladu s potrebama učenika, od kolike su važnosti učenicima okolni oblici koji se s njima mogu povezati i slično. Na početnoj razini treba izbjegavati leksik koji je suvišan za zadovoljavanje neposrednih potreba ili može izazvati konceptualne poteškoće, treba radije uvoditi onaj koji je prikladan za neposrednu uporabu u skladu s potrebama učenika na tom stupnju.

Koncept značenja vrlo je kompleksan i stoga je u nastavnom procesu potrebno provoditi različite aktivnosti da se spozna i prihvati da različiti aspekti značenja trebaju biti prirodni, sastavni dio nastavnog procesa učenja stranog jezika.

Ispravan pristup podučavanju vokabulara vrlo je značajan, tim više što je važna i njegova uloga u razvijanju jezičnih vještina, a prikladnost aktivnosti i tehnika koje se primjenjuju tijekom nastavnog procesa bitno određuje uspješnost usvajanja vokabulara. 


\section{POPIS LITERATURE}

BREWSTER, ELLIS, GIRARD 1991

J. Brewster, G. Ellis, D. Girard, The Primary English Teacher's Guide, Penguin English, London 1991.

\section{KOVAČEVIĆ 2007}

M. Kovačević, "Nastava jezika u ranoj dobi: Razvoj nastavnikove samospoznaje", Strani jezici, 36/3, 2007., 199-205.

\section{KRASHEN 1982}

S. D. Krashen, Principles and Practice in Second Language Acquisition, Pergamon Institute of English, New York 1982.

\section{LEWIS 1993}

M. Lewis, The Lexical Approach, The State of ELT and a Way Forward, Language Teaching Publications, London 1993.

\section{NATION 2001}

I. S. P. Nation, Learning Vocabulary in Another Language, Cambridge University Press, Cambridge 2001.

\section{OXFORD 1990}

R. Oxford, Language Learning Strategies: What Every Teacher Should Know, Heinle \& Heinle, Boston 1990.

\section{PAVIČIĆ 2000}

V. Pavičić, "Istraživanje strategija učenja vokabulara", Strani jezici, 29/1-2, 2000., 15-25.

\section{PAVIČIĆ TAKAČ, UMILJANOVIĆ 2008}

V. Pavičić Takač, A. Umiljanović, "Odnos između znanja i strategija učenja vokabulara u engleskom kao stranom jeziku", Strani jezici, 37/4, 2008., 411-422.

\section{PEDERSEN 1995}

E. M. Pedersen, "Storytelling and the Art of Teaching", English Teaching Forum 33/1, 1995, 2-5.

\section{PETROVIĆ 1988}

E. Petrović, Teorija nastave stranih jezika, Školska knjiga, Zagreb 1988.

\section{PHILLIPS 1993}

S. Phillips, Young Learners, Oxford University Press, Oxford 1993.

READ 2000

J. Read, Assessing Vocabulary, Cambridge University Press, Cambridge 2000.

\section{RIVERS, TEMPERLY 1978}

W. M. Rivers, M. S. Temperly, A Practical Guide to the Teaching of English as a Second or Foreign Language, Oxford University Press, Oxford 1978.

\section{VICKOV 2008}

G. Vickov, "O vokabularu u ranom učenju stranog jezika", Strani jezici, 37, 2008., 337-357.

\section{VILKE 1991}

M. Vilke, Vaše dijete i jezik, Školska knjiga, Zagreb 1991.

\section{VILKE 1993}

M. Vilke, "Djeca i strani jezici", Strani jezici, 22/3-4, 1993.

\section{VILKE 1995}

M. Vilke, Children and Foreign Languages in Croatian Primary Schools. Children and Foreign Languages, Faculty of Philosophy University of Zagreb, Zagreb 1995.

\section{VILKE 1999}

M. Vilke, "Obrada rječnika", u: Vrhovac, Y. i

suradnici, Strani jezik u osnovnoj školi, Naprijed, Zagreb 1999., 179-186.

\section{VILKE 1999}

M. Vilke, "Djeca i učenje stranih jezika u našim školama", u: Vrhovac, Y. i suradnici, Strani jezik u osnovnoj školi, Naprijed, Zagreb 1999, 17-29. 


\section{THE ACQUISITION OF VOCABULARY OF ENGLISH LANGUAGE ET EARLY AGE}

The paper deals with the acquisition of vocabulary by young learners. Early foreign language learning should help the learners to acquire better a new linguistic code as a means of commuinication. Communicative approach focuses the study of vocabulary at the heart of language teaching and language learning. This is the most favourable age to develop and improve their auditory, phonotory and imitative faculties. Considering the particular characteristics and abilities that young learners have, during the teaching process they should be encouraged to employ strategies of spontaneous learning, since they may have positive effect on the acquisition of vocabulary in the target language. In teaching language learning skills the priority should be given to developing listening and speaking skills, as young learners should master reading and writing in their mother tongue first. As children enjoy listening to stories, we can make good use of storytelling because it is motivating and fun, it exercises imagination, it is a useful tool in linking fantasy and imagination with the child's real world, and it is definitely a rich source of context for vocabulary teaching and learning.

Key words: young learners, language teaching skills, vocabulary, activities and teaching techniques 